\title{
FETAL DEATHS IN MARANHÃO STATE (BRAZIL), IN THE YEARS OF 2000, 2010 AND 2014
}

\author{
Mayanna karlla Lima Costa ${ }^{1,}$, Vilena Aparecida Ribeiro Silva ${ }^{1}$, Raimunda Alves Silva ${ }^{1}$
}

${ }^{1}$ Doctorate in Program of Biodiversity and Biotechnology Network of the Legal Amazon- BIONORTE. Federal University of Maranhão. São Luís, MA. Campos Universitário do Bacanga - Centro de Ciências Exatas e Tecnologia Av. dos Português, s/n - São Luís/MA - CEP: 65085-580.

*Corresponding author: mayannakarlla@hotma.com

Received: Aug. 01, 2017 - Accepted: Nov. 12, 2017

DOI: http://dx.doi.org/10.22615/2526-1746-jgm-2.3-6864

ABSTRACT: The occurrence of a high number of fetal deaths is present throughout the world. It is estimated that more than 2 million fetal deaths occur each year on the globe, where 98\% predominate in developing countries. This research aimed to carry out the survey of the fetal deaths number in Maranhão state, as a way to bring contributions to theprevention and health care actions. Data from DATASUS were used for the survey of fetal deaths occurring in the 217 municipalities in Maranhão state in the years 2000, 2010 and 2014, as well as the fetal mortality rate. The program SURFER ${ }^{\circledast}$ version 11.0 were usedfor descriptive statistics analysis and construction of the mean distribution map of cases. The fetal mortality rate in Maranhão has increased over the years, not following the national trend of reduction of intrauterine mortality rates, being required greater investment in public policies to analyze the main risk factors in the state.

Key words: fetal death, public health, fetal mortality rate.

\section{ÓBITOS FETAIS NO ESTADO NO MARANHÃO (BRASIL), NOS ANOS DE 2000, 2010 E 2014}

RESUMO: A ocorrência de um elevado número de óbitos fetais está presente em todo o mundo. Estima-se que mais de 2 milhões de óbitos fetais ocorrem por ano no globo, onde 98\% predominam nos países em desenvolvimento. Esta pesquisa teve como objetivo realizar o levantamento do número de óbitos fetais no estado do Maranhão, como forma de trazer contribuições para ações de prevenção e atenção à saúde. Foram utilizados dados do DATASUS para o levantamento dos óbitos fetais ocorridos nos 217 municípios do estado do Maranhão nos anos de 2000, 2010 e 2014 , bem como a taxa de mortalidade fetal. Foi utilizado o Programa SURFER ${ }^{\circledR}$ versão 11.0 para análise de estatística descritiva e construção do mapa de distribuição da média dos casos. A taxa de mortalidade fetal no Maranhão aumentou ao longo dos anos, não acompanhando a tendência nacional de redução dos índices de mortalidade intraútero, sendo necessário maior investimento em políticas públicas para a análise dos principais fatores de risco no estado.

Palavras-chave: morte fetal, saúde pública, taxa de mortalidade fetal. 


\section{INTRODUCTION}

The occurrence of a high number of fetal deaths is present throughout the world. It is estimated that more than 3 million fetal deaths occur each year on the globe, where 98\% predominate in developing countries (Vieira et al., 2016). This number may be even higher, in view of the low reliability of the information provided and a high number of occurrence underreported. (BARBEIRO et al., 2015).

Still, this is a topic with little emphasis on the global political agenda. Unlike the efforts to reduce the mortality of mothers and children, established on the aims of the Millennium Development Goals by 2015, the decrease of intrauterine deaths was not included as a priority in this document, remaining until now undervalued in public health programs both internationally and locally (VIEIRA et al., 2012).

In Brazil, the Ministry of Health considers as fetal death the product of conception with weight greater or equal to $500 \mathrm{~g}$ and/or gestational age greater or equal to 22 weeks (Lima et al., 2016). Intrauterine deaths are potentially preventable and well-conducted actions are fundamental for the effective reduction of mortality rates (FLENADY et al., 2017).

Despite all this relevance from the point of view of public health, there are still few Brazilian studies available on fetal deaths. Even rarer still studies in this field in the state of Maranhão. This way, this research aimed to carry out the survey of the fetal deaths number in Maranhão state, as a way to bring contributions to the prevention and health care actions.

\section{MATERIAL AND METHODS}

A longitudinal study was carried out, with a quantitative approach, on the characterization of the fetal deaths occurred in the state of Maranhão. This study was developed with data from the public domain, available in the database of the Informatics Department of the Unified Health System (DATASUS). These data are provided by the Mortality Information System (SIM) and the Live Birth Information System (SINASC). In order to calculate the fetal mortality rate according to the regions of the country, equation 1 was used.

$$
\frac{n 1}{n 1+n 2} * 1000
$$

wherein: $N 1=$ Number of fetal deaths; N2: Number of live births

The data were divided according to the year and by municipalities belonging to the state of Maranhão, totaling 217 municipalities. Two groups were analyzed: the first one consisted of municipalities with a population of 50,000 to 100,000 inhabitants and the second one by municipalities above 100,000 .

The data were analyzed by descriptive statistics using the program SURFER ${ }^{\circledR}$ version 11.0, calculating the minimum value, maximum value, mean, standard deviation, coefficients of variation (CV), skewness and kurtosis. CV was classified according to WARRICK and NIELSEN (1980) below (CV $\leq 12)$, moderate $(12<C V<60)$ and high $(C V \geq 60)$. The normality of the data was verified by the Kolmogorov-Smirnov test (KOLMOGOROV and SMIRNOV, 1933) at $1 \%$ significance. The same 
program was also used to construct the distribution map of the mean number of cases of fetal deaths in the three years evaluated in the state of Maranhão.

\section{RESULTS AND DISCUSSION}

The parameters referring to the descriptive analysis of the fetal deaths data in the municipalities of Maranhão state in the years 2000, 2010 and 2014 are described in table1.

Table 1. Statistical parameters for the mean of fetal deaths in the municipalities of the State of Maranhão carried out in the years 2000, 2010 and 2014.

\begin{tabular}{ccccccccccc}
\hline Fetal deaths & N & Min & Max & Mean & Variance & SD & CV & Skew & Kurtosis & D \\
\hline 2000 & 217 & 1 & 4009 & 75 & 82400 & 287 & 382 & 12.214 & 165.3 & $0.398 \mathrm{Ln}$ \\
2010 & 217 & 6 & 4942 & 120 & 127866 & 357 & 297 & 11.712 & 155.053 & $0.375 \mathrm{Ln}$ \\
2014 & 217 & 16 & 5945 & 147 & 184272 & 429 & 290 & 11.744 & 155.917 & $0.375 \mathrm{Ln}$
\end{tabular}

Min.: minimum value Max: maximum value; SD = standard deviation. CV = coefficient of variation. $\mathrm{D}=1 \%$ Error probability by Kolmogorov-Smirnov teste. $\mathrm{n}=$ normal. $\mathrm{Ln}=$ lognormal.

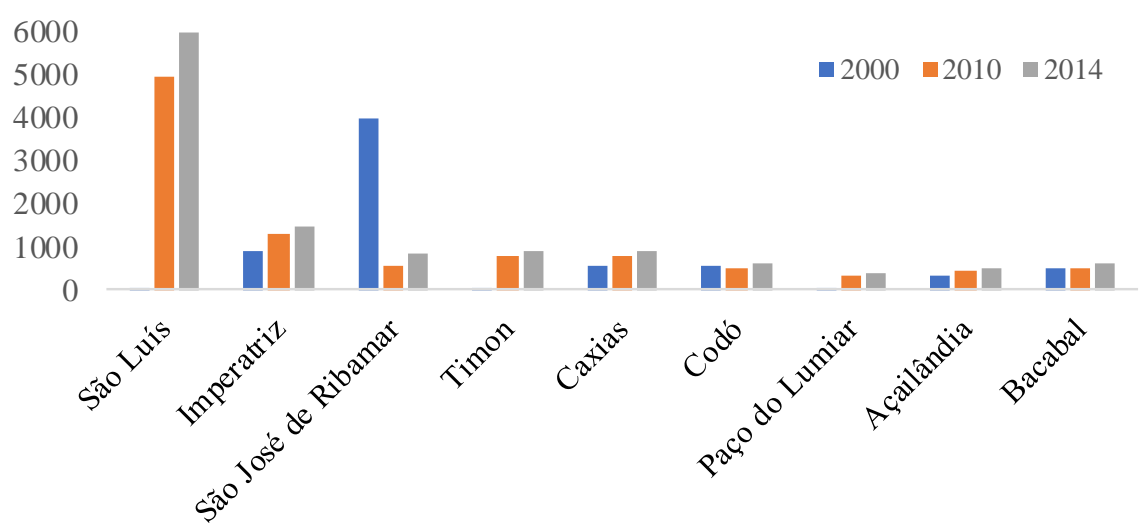

Figure 1. Number of fetal deaths per household in the years 2000, 2010 and 2014.

Fetal deaths

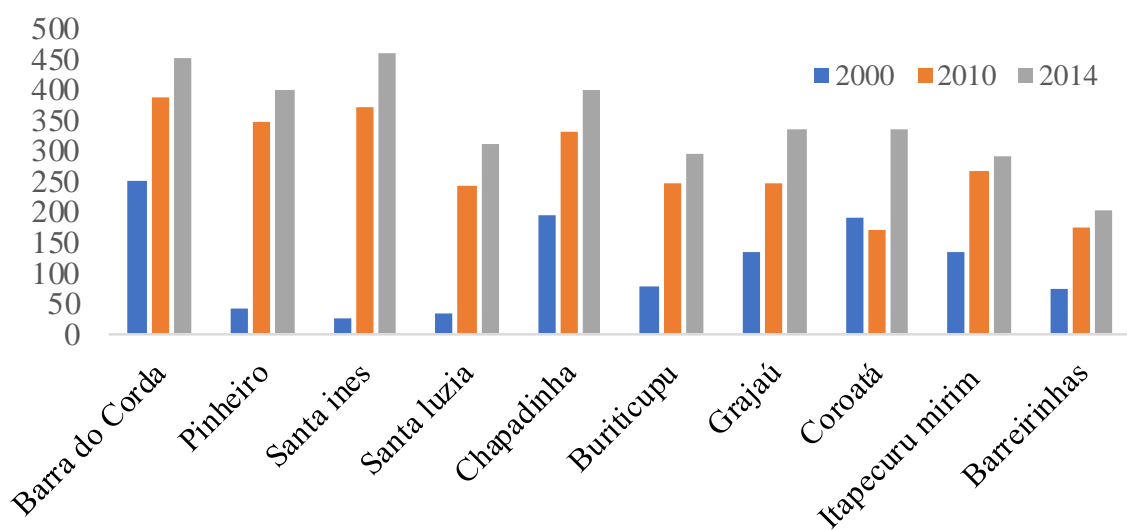

Figure 2. Number of fetal deaths per household in the years 2000, 2010 and 2014, in the municipalities of Maranhão with a population of 50,000 to 100,000 inhabitants 


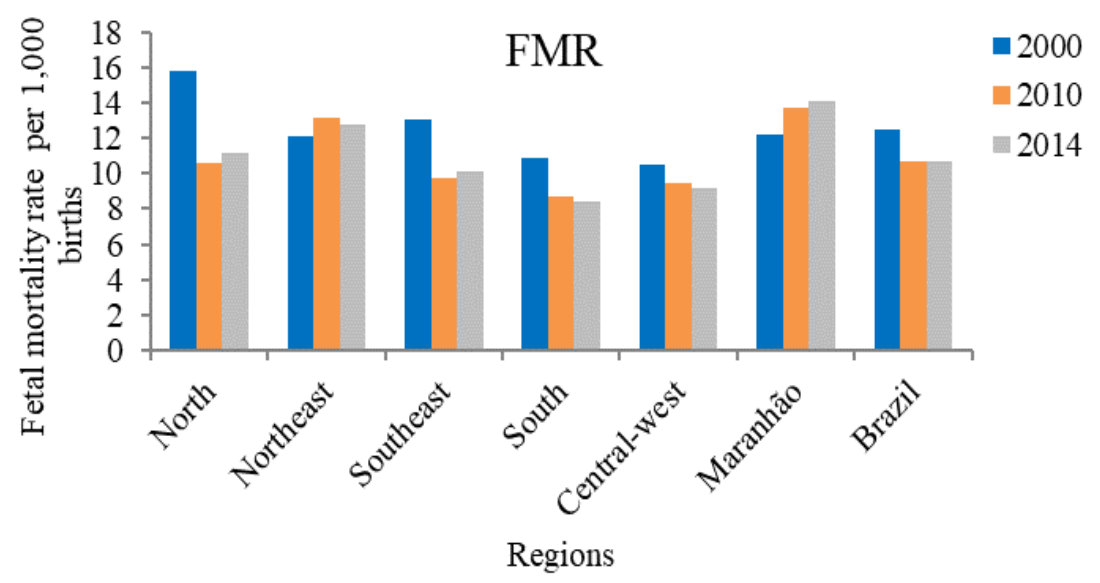

Figure 3. Comparison of the Fetal Mortality Rate between Maranhão and other regions of Brazil

It is observed an increase in the value of the general mean of the municipalities with the passage of the years in the evaluated period when it went from the mean of 75 in 2000 to 147 fetal deaths in 2014. There was an increase of $49 \%$, representing an increase of $3.5 \%$ per year. The CV values for all the years were high $(>290 \%$, ) and also were observed high values of variance. This behavior was expected, because there are several factors that affect the number of fetal deaths in each municipality, including socioeconomic and demographic variables, besides the mother's age, access to health services and quality of prenatal care, diseases during the pregnancy, genetic aspects, among others (ASSIS et al., 2014; PARIS et al., 2016; PAULA JÚNIOR 2016).

According to figure 1 , an increase is observed in the number of fetal deaths over the years in all municipalities in Maranhão with a high population index (above 100,000 inhabitants), with a mean of 714 in the years 2010 and 2014. The state capital, São Luís, was the one that presented the highest increase in the number of cases of the year
2000 in relation to the years 2010 and 2014, with a mean increase of $20 \%$ per year.

The same behavior is observed for all municipalities with a population of 50,000 to 100,000 inhabitants (Figure 2). The municipalities of Codó, Açailândia, and Bacabal obtained a low variation in the number of fetal deaths in the three evaluated periods, with means of 554, 441 and 495 fetal deaths, respectively.

The cities of Pinheiro, Santa Inês, Santa Luzia and Buriticupu had a mean increase of $88 \%, 93 \%, 85 \%$ and $72 \%$ in the number of fetal deaths in 2000 compared to the other years, respectively. This fact can be explained by the changes in the demographic parameters accentuated in the period. Besides this, these values may reflect unfavorable conditions of the population life, health care, besides regional and socioeconomic inequalities observed in the municipalities of the interior of the state (RAFAEL et al., 2011; TRINDADE et al., 2011; BARBEIRO et al., 2015).

The fetal mortality rate (FMR) is expressed as the number of fetal deaths divided by the number of total births added to fetal deaths and multiplied by one thousand. It was 
verified that the Maranhão state did not follow the trend of reduction of the rate as observed in the other regions (Figure 3 ).

When evaluating fetal death in different regions of the country, we found considerable differences between regions. In 2000, the stillbirth rate ranged from $15.7 / 1000$ births in the North to $10.4 / 1000$ in the Midwest. Over the years (from 2000 to 2014), the Southeast Region had the largest reduction in the stillbirth rate, with a drop of $22.5 \%$ (from 13.0 to $10.1 / 1000)$. The South has the lowest rates since 2000. In 2014, the rate was 8.4/1000. On the other hand, the Northeast region has the highest rates since 2000, with the rate of 12.7 in 2014.

Being Brazil a country of continental dimensions, and with great social inequality, may be observed that access to health care services has considerable differences from one region to another, as evidenced by the presented data. In Maranhão, FMR increased from 12.1/1000 in 2000 to 14.0/1000 in 2014, a fact that needs greater attention to understand the causes of being divergent from the national trend.

The main causes of death according to the literature are prematurity, congenital malformation, intrapartum asphyxia, perinatal infections and maternal factors, but there is also a considerable proportion of deaths preventable by health services (LAWN et al., 2016; FLENADY et al., 2017).

Through the distribution map of the mean of the fetal deaths cases in the state, is possible to observe the regions with the highest number of fetal deaths in the three years evaluated (Figure 4).

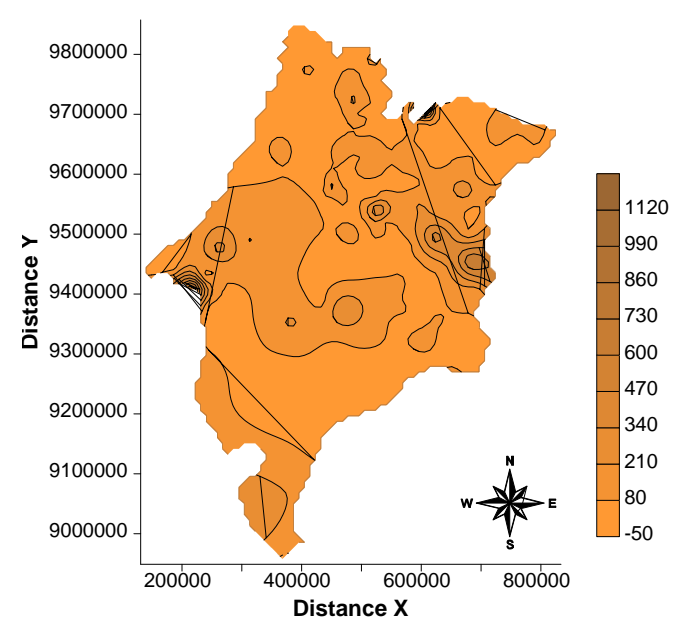

Figure 4. Mean distribution of the number of fetal deaths per household in the municipalities of the State of Maranhão (Years: 2000; 2010;2014).

According to the map, the municipalities belonging to the northern mesoregion (which includes the capital São Luís) and the eastern of Maranhão, were the ones that obtained the highest number of cases.

\section{CONCLUSION}

The numbers of fetal deaths recorded in Maranhão in the years 2000, 2010 and 2014 by the municipality are considered high and increasing when related to the mean rates of other states and regions of the country.

The prevention of fetal death requires high-quality information on the causes of death as well as on the evolution of pregnancy. Most of the studies on the subject do not bring this information. Therefore, the need for greater investment in research in this area.

\section{REFERENCES}

Assis, H. M.; Siviero, P.C.L.; Drumond, E.F.; Machado, C. J. 2014. Óbitos fetais sob o 
prisma da evitabilidade: análise preliminar de um estudo para o município de Belo Horizonte. Cadernos de Saúde coletiva [online]. v.22, n.3, pp.314-317.

Barbeiro F M S, Fonseca, S C; Tauffer, M. G.;Ferreira, M.S.C.;Silva, F.P.;Ventura, P;M.; Quadro, J.I. 2015. Óbitos fetais no Brasil: revisão sistemáticaRevista de Saúde Pública v.1, n.1, p:49-22.

Flenady, V.; Wojcieszek, A.M. Ellwood, D. et al. 2017. Classification of causes andassociatedconditions for stillbirthsandneonatal deaths. Seminars in Fetal \& Neonatal Medicine, v. 1, p.1-10.

Lawn, J.E.; Blencowe, H;Waiswa,P.;Amouzou, A.; Mathers, C.; Hogan, D.; 2016. for the Lancet Ending Preventable Stillbirths series study group. Stillbirths: rates, riskfactors, and acceleration towards 2030. Lancet, v.387, n.10018, 'p.587-603.

Paula Júnior, J.D.; Lucas, E.S.; Cunha, L.M.C.; Machado, M.G.M.; Pedrosa, R.L. 2016. Perfil da mortalidade neonatal no município de Ubá/MG, Brasil (2008-2010), Revista Brasileira de Pesquisa em Saúde, v.18, n.3,p.24-31.

Rafael, R.A.A; Ribeiro, V.S.; Cavalcante, M.C.V.; Santos, A.M.; Simões, V.M.F.; 2011. Relacionamento probabilístico: recuperação de informações de óbitos infantis e natimortos em localidade do Maranhão, Brasil. Cadernos de Saúde Pública, v.27, n.7, p:1371-9.

Trindade, L.L.; Amestroy, S.C.;Piolo, D.; Falchetti, G; Milbrath, V.M. 2011. Fatores de risco para morte fetal no município de Pato Branco (Brasil). Investigación y Educación em Enfermaria. v. 29, n.3, p:451-458.

Vieira, M.S.M.;Siebert, E.C.; Ceglio, W.Q.G.W.; Almeida, M.H.; Batista, T.S.; Freitas P.F. 2012. Dificuldades para a identificação da causa do óbito fetal: como resolver? Revista Brasileira de Ginecologia e Obstetrícia, v.34, n.9, p:4038.

Vieira, M.S.M.; Vieira, F.M.;Fröde, T.S. et al. 2016. Fetal Deaths in Brazil: Historical Series Descriptive Analysis 1996-2012. Maternal and Child Health Journal, v.20, n.8, p:1634-1650. 